\title{
EMPRESARIALES
}

\section{Incidencia económica y financiera de los apalancamientos para Mipymes de la Cooperativa Ayacape Ltda. del periodo 2008 hasta el 2012}

\author{
Rubén M. González Medina
}

\section{Resumen}

Introducción: El cooperativismo es un movimiento extendido por todo el mundo que se caracteriza por propiciar la asociación de personas en base a esfuerzo propio y la ayuda dentro de un clima de libertad, justicia y solidaridad, para mejorar la calidad de vida y la dignidad humana, respetando para ello un conjunto de principios universales que son su fundamento.

Se puede decir que las Cooperativas constituyen un cambio o innovación en la estructura del sector financiero y económico, ya que presenta un manejo distinto en cuanto a lo Institucional, en lo crediticio y en lo que se refiere a la forma de otorgar los préstamos a los socios Microempresarios, y Pequeños Empresarios. No obstante, hasta el momento no existen estudios sistemáticos realizados que pudiesen dar sustentación firme a dichos comentarios, razón por la cual se decidió verificar la incidencia Económica y Financiera de los Préstamos a los Pequeños Empresarios y Microempresarios de la Cooperativa Ayacapé Ltda. en una investigación descriptiva, de diseño no experimental y de corte transversal.

Objetivo: Analizar la Incidencia económica y financiera del apalancamiento para los Mipymes de la Cooperativa Ayacape Ltda. del periodo 2008 hasta el 2012.

Metodología: La técnica elegida para este análisis fue la revisión documental. El análisis de los datos obtenidos se realizó de manera numérica o estadística, es decir, los datos fueron tabulados y graficados con un análisis del mismo.

Resultados: Para obtener estos resultados se tomaron una muestra de 50 socios del sector Mipymes que obtuvieron el apalancamiento financiero entre el periodo del 2008 hasta el 2012 respectivamente de dicha Institución mencionada más arriba y a continuación se detallan los rubros que se dedican a la producción de bienes son: Carpintería, agricultura, modistería y los rubros que se dedican al servicio son: Ventas varias, odontología, peluquería, farmacia,

\footnotetext{
1. Universidad Nacional del Este.

Tesis para obtener el título de Máster en Administración de Empresas de la Facultad de Ciencias Económicas de la Universidad Nacional del Este.

E-mail: gonzalezmedinarubenmilciades@gmail.com

DOI: $10.26885 /$ rcei.foro. 2018.86
} 
contabilidad, informática, mecánica. Estos rubros, servicios y bienes fueron los analizados y estudiados para la investigación de la misma.

Conclusión: Teniendo en cuenta los resultados obtenidos en este trabajo de investigación se concluye que el tipo de apalancamiento denominado Mi Pymes tuvo un comportamiento favorable y aceptado por los socios que operan en el rubro, teniendo en cuenta el beneficio que recibe los asociados como la facilidad, rapidez y bajos intereses que ejecutan para inversión.

Los diferentes rubros estudiados que tuvimos en cuenta para nuestra investigación son los más importantes teniendo en cuenta la base de datos de la Institución.

Como conclusión de este trabajo podemos puntualizar que hubo un comportamiento en forma ascendente teniendo un promedio porcentual entre el $3 \%$ y $30 \%$ respectivamente.

Palabras clave: solidaridad, apalancamiento financiero, beneficio, facilidad, rubro, incidencia.

\section{Referencias}

Alarcón. L. (2010). Las Empresas Cooperativas: Un Enfoque Estructural, Normativo y Técnico. Asunción: Edición a cargo del Autor.

Cooperativa Ayacape Ltda. (2015). Préstamo de rubro Mipymes del periodo 2008 hasta 2012: Extractos de los 50 socios: INCOOP.

Dietze, R.(2001). El Censo Nacional de Cooperativa y algo más. Asunción: Edición: A cargo del Autor.

Figueredo, E.(2018). Estatuto Social de la Cooperativa Ayacape Ltda. Ciudad del Este.

González, H. (2015). Marco legal del sector cooperativo paraguayo. Asunción: Edición Revisado y Actualizada.

Pettit, H. (2008). Economía Social y Empresa. Alemania. 